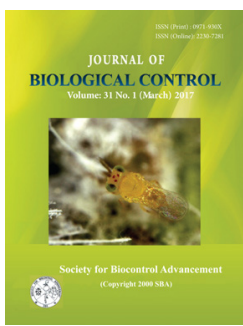

\title{
Natural parasitoids of fruit piercing moth, Eudocima spp.
}

\author{
P. N. MAGAR* ${ }^{*}$ S. R. KULKARNI and A. G. CHANDELE \\ Department of Entomology, Post Graduate Institute, Mahatma Phule Krishi Vidyapeeth, Rahuri, Dist. Ahmednagar - 413722 , \\ Maharastra, India \\ "Corresponding author E-mail: pramodmagar08@gmail.com
}

\begin{abstract}
Eudocima spp. (Noctuidae) also known as fruit piercing moth, is a serious pest of tropical countries including subtropical Southeast Asia, Australia, and the western Pacific islands. It is found commonly occurring on ripening fruits. Surveys conducted in Maharashtra revealed that three abundant larval parasitoids viz., a tachinid fly, Goniophthalmus halli, eulophid wasps, Euplectrus maternus and Tetrastichus sp. were contributing up to $36.65,41.46$ and $36.58 \%$ larval mortality, respectively. Laboratory assays were conducted to test the parasitoids for host specificity by exposing them to larvae of Eudocima sp. However, Goniophthalmus halli showed parasitization on other species of Eudocima, whereas E. maternus was found to be host specific on E. materna. In laboratory investigation, 72 to $89 \%$ parasitization of Trichogramma chilonis on the eggs of E. materna was also recorded.
\end{abstract}

KEY WORDS: Eudocima spp., fruit piercing moth, larval parasitoids

(Article chronicle: Received: 22.02.2017; Revised: 24.03.2017; Accepted: 31.03.2017)

\section{INTRODUCTION}

Adult fruit piercing moth (Eudocima spp.) is a destructive pest of ripening fruits in tropical and subtropical countries including India, Africa, Southeast Asia, Australia and the South Pacific (Waterhouse and Norris 1987). The moths are destructive as their long, serrated, sharp, stout proboscis can puncture the rind of ripening fruits to feed on the fruit juice and pulp. Punctured fruits are exposed to secondary infections by bacteria and fungi leading to rot and premature fruit-fall (Sands et al., 1993). The larvae of fruit piercing moths feed on several vines viz., Tinospora cardifolia, Cocculus hirsutus, Anamirta cocculus, Diploclisa glaucescens and Tiliacora acuminata (Lam.) of the family Menispermaceae which are generally located nearby rivers and inaccessible water back areas. The moths can travel hundreds of kilometers and orchards located nearer to breeding areas are more prone to the pest attack. It is also observed that these moths migrate from breeding sites to orchards, which are often very distant to one another. The immature stages of the moth survive only on twining vines of the family Menispermaceae occurring in scrub and forest areas, often remote from orchards and hence it is difficult to control this pest (Fay, 1996 and Denton et al., 1991). In India, studies on management of this pest is very limited in spite of it being a serious pest of the fruits in tropical countries. Their mode of damage to ripening fruits enables them to have insufficient contact with chemicals and escapes from knockdown effect. Also adequate holding period is not achieved as ripe fruits are normally attacked. Hence biological control using egg and larval parasitoids is a safe and better alternative to manage these fruit piercing moths. Hence, the investigation was planned to find out natural enemies of fruit piercing moths and extent of their parasitization.

\section{MATERIALS AND METHODS}

The efforts were made to identify and collect natural enemies of fruit piercing moth by conducting survey at MPKV campus and river bank areas in Ahmednagar Region and Paithan (Aurangabad Region) of Maharashtra where larval host plants were available.

Parasitization by egg-parasitoid Trichogramma chilonis on eggs of Eudocima materna under laboratory condition

No parasitized eggs of fruit piercing moth were found in nereby Menispermaceae plants. Therefore, Trichocards (already parasitized by Trichogramma chilonis) were procured from Bio-control laboratory, Department of Entomology, College of Agriculture, Pune, Maharashtra to study the per cent parasitization of $T$. chilonis on eggs of $E$. materna under laboratory condition. Five sets of 100 eggs 
were spread on yellow paper $(1 \mathrm{~cm} \mathrm{X} 4 \mathrm{~cm})$ smeared with the glue and were kept in the transparent polythene bag with one strip of Trichocard $(1 \mathrm{~cm} \mathrm{X} 4 \mathrm{~cm})$ and the top end of the polythene bag was closed tightly. The observations on parasitization were recorded from next day.

Natural parasitization by eulophid wasps, (Euplectrus maternus and Tetrastichus sp.) and tachinid fly, Goniophthalmus halli Mesnil on larvae of fruit piercing moth

The field collected larvae were critically observed under microscope for parasitization and parasitized larvae were recorded after every field collection. The collected specimens of parasitoids were identified from National Project on Insect Biosystematics, Division of Entomology, IARI, New Delhi.

\section{RESULTS AND DISCUSSION}

\section{Study on natural enemies of fruit piercing moths}

In the investigation during field survey, one egg parasitoid, Trichogramma chilonis, larval parasitoids i.e eulophid wasps (Euplectrus maternus and Tetrastichus sp.) and a tachinid fly, Goniophthalmus halli were reported parasitizing the eggs and larval stage of fruit piercing moth.

Per cent parasitization by Trichogramma chilonis on eggs of Eudocima materna under laboratory condition

The per cent parasitization by Trichogramma chilonis on eggs of E. materna is presented in Table 1 and it was revealed that $T$. chilonis was promising and effective egg parasitoid parasitizing about $80.67 \%$ eggs. The egg parasitization ranged from 72.0 to $89.0 \%$ under laboratory conditions. Similar observations were recorded by Maddison (1982) who reported parasitization by Trichogramma sp. on eggs of fruit piercing moth. Kumar and Lal (1983) recorded T. papilionis parasitizing the eggs of $O$. fullonia to the extent of 7.7-50.5 per cent from Fiji. Dodia et al. (1986) demonstrated the successful parasitization of T. chilonis on the eggs of $O$. fullonia. Bhumannavar (2000) recorded that T. chilonis were parasitizing eggs of E. materna. Bhumannavar and Viraktamath (2001) recorded the mean per cent parasitization of eggs of Eudocima by T. chilonis during 1998 to be $21.45 \pm 27.45$ and during 1999 to be 50.40 \pm 34.08 .

Table 1. Per cent parasitization by egg parasitoid, Trichogramma chilonis on eggs of fruit piercing moth under laboratory condition

\begin{tabular}{|l|l|l|}
\hline $\begin{array}{l}\text { No. of eggs ex- } \\
\text { posed }\end{array}$ & $\begin{array}{l}\text { No. of eggs parasit- } \\
\text { ized }\end{array}$ & $\begin{array}{l}\text { Per cent parasitiza- } \\
\text { tion }\end{array}$ \\
\hline 100 & 89 & $89.0 \%$ \\
\hline 100 & 72 & $72.0 \%$ \\
\hline 100 & 81 & $81.0 \%$ \\
\hline & Mean & $80.67 \%$ \\
\hline
\end{tabular}

Natural parasitization by eulophid wasp, Euplectrus maternus and Tetrastichus sp. on early instar larvae of fruit piercing moth during 2012-13

The natural parasitization of eulophid wasps is presented in Table 2 and it was revealed that the per cent natural larval parasitization by eulophid wasps, Euplectrus maternus and Tetrastichus sp. was $41.46 \%$ and $36.58 \%$ on early instar larvae FPM, respectively. The parasitoids, Euplectrus and Tetrastichus sp. were found to be typically parasitizing to the larvae near the eye spot bearing region on $3^{\text {rd }}$ and $4^{\text {th }}$ abdominal segment and eggs laid on this region also observed on field collected larvae. These parasitoids were found to be specific $2^{\text {nd }}$ and $3^{\text {rd }}$ instar larvae. The present results are inconformity with Ayyar (1944) who recorded Tetrastichus ophiusae as larval parasitoid on both Ophideres and Achaea species. Bhatnagar (1957) reported a eulophid wasp, Euplectrus maternus on $O$. fullonia and $O$. materna from Uttar Pradesh (India). Euplectrus maternus parasitized first three larval instars of E. materna, E. fullonia and E. homaena (Bhumannavar, 2000). Muniappan et al. (2004) studied the biology of E. maternus on E. fullonia larvae in Guam and their attempts to establish this parasitoid in the field failed. The present findings were in agreement with the reports of these workers.

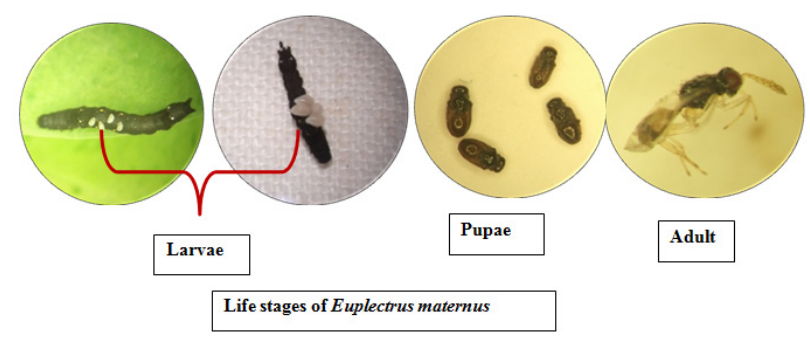

Natural parasitization by tachinid fly, Goniophthalmus halli Mesnil on late instar larvae of fruit piercing moth during 2012-13

Data pertaining to the natural parasitization of tachinid fly, Goniophthalmus halli Mesnil presented in Table 2, it was revealed that 81 out of 221 collected larvae of fruit piercing moth were parasitized by $G$. halli and the average per cent parasitization of late instar larvae was recorded as 36.65 per cent. The natural parasitization of $G$. halli was observed from last week of September to the end of October during 2012-13. The fly usually laid its eggs on the fifth instar larvae and the eggs hatched in 3-3.5 days. The maggots penetrated into the body of Eudocima sp. caterpillar and fed inside on the body fluids, until the caterpillar pupated.

Maddison (1982) reported a tachinid fly, Winthemia caledoniae an important larval parasitoid of $O$. fullonia from New Caledonia. The fly usually laid its eggs on the fifth instar larvae. Cochereau (1977) reported Winthemia 
Natural parasitoids of fruit piercing moth, Eudocima spp.

Table 2. Natural parasitism of different larval parasitoids of fruit

\begin{tabular}{|l|l|l|l|}
\hline Natural Enemy & No. of larvae collected & No. of Parasitized larvae & Per cent parasitization \\
\hline Tetrastichus sp. & \multirow{2}{*}{ 41 (Early instars) } & 17 & $41.46 \%$ \\
\cline { 3 - 4 } Euplectrus maternus & & 15 & $36.58 \%$ \\
\hline Goniophthalmus halli & 221 (Late instars) & 81 & $36.65 \%$ \\
\hline
\end{tabular}

caledoniae larval parasitoid accounting 25-46 per cent parasitization in New Caledonia. Bhumannavar and Viraktamath (2001) reported parasitization by Winthemia sp. to be $51.5 \pm 24.07$ per cent on fifth instar larvae of E. maternus and it did not parasitize other species of Eudocima. Jayanthi and Verghese (2010) recorded up to 40 per cent parasitization of E. maternus larvae by Winthemia sp. The present findings were in agreement with the reports of these workers.

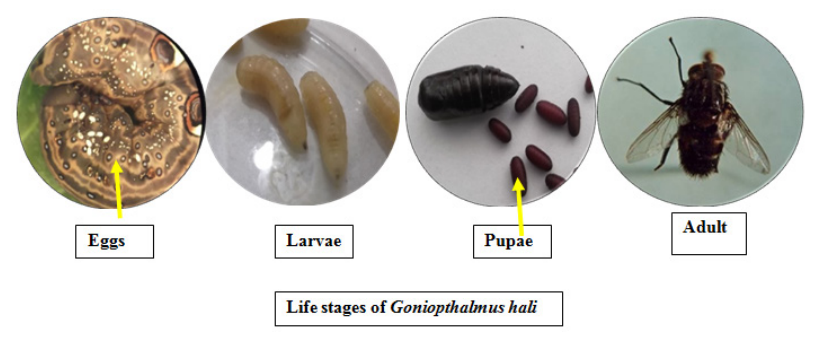

\section{REFERENCES}

Ayyar TVR. 1944. Notes on some fruit sucking moths of the Deccan. Indian J Entomol. 5: 29-33.

Bhatnagar SP. 1957. Description of new and records of known Chalcidoidea (Parasitic Hymenoptera) from India. Indian J Agric Sci. 21: 155-178.

Bhumannavar BS. 2000. Studies on fruit piercing moths (Lepidoptera: Noctuidae) - species composition, biology and natural enemies. Ph. D. Thesis submitted to University of Agricultural Sciences, GKVK, Bangalore. 181pp.

Bhumannavar BS, Viraktamath CA. 2001. Seasonal incidence and extent of parasitisation of fruit piercing moths of the genus Othreis (Lepidoptera: Noctuidae). $J$ Biol Contr 15 (1): 31-38.

Cochereau P. 1977. Biologie et ecologie des populations en Nourelle-calodonie d'un papillon piquer de fruits : Othreis fullonia Clerck. Cahiers ORSTOM SerieBiologie 71: 322.

Denton GRW, Miniappan R, Murutani M, McCannell J, Lali TS. 1991. Biology and natural enemies of the fruit-piercing moth, Othreis fullonia (Lepidoptera: Noctuidae) from Guam. In: Proceedings, Agriculture Development in the American Pacific, Crop Protection Conference, Honolulu, H1, May 18-19, 1989, Pp. 150154, Univ. of Hawaii Research Extension Series, 134 pp. 180.

Dodia JF, Yadav DN, Patel RC. 1986. Management of fruit sucking moth, Eudocima fullonia $\mathrm{Cl}$. (Lepidoptera : Noctuidae) in citrus orchards at Anand (Gujarat). Gujarat Agric Univ Res J. 11: 72-73.

Fay HAC. 1996. Evolutionary and taxonomic relationships between fruit-piercing moths and the Menispermaceae. Aust Syst Bot. 9(2): 227-233.

Jayanthi PDK, Verghese A. 2010. Natural parasitization of larvae of fruit piercing moth, Eudocima (= Othreis) materna. Insect Environ. 16(2): 67.

Kumar K, Lal SN. 1983. Studies on the biology, seasonal abundance and host parasite relationship of FSM, Othreis fullonia (Clerck) in Fiji. Agric J. 45: 71-77.

Maddison PA. 1982. Fruit piercing moth. South Pacific Commission leaflet 14, Entomology Division, DSIR, Auckland, New Zealand, 4 pp.

Muniappan R, Bamba J, Cruz J, Reddy GVP. 2004. Biology, rearing and field release on Guam of Euplectrus maternus, a parasitoid of the fruit-piercing moth, Eudocima fullonia. Biol Control. 49(5): 537-551.

Sands DPA, Liebregts WJMM, Broe RJ. 1993. Biological control of the fruit piercing moth, Othreis fullonia (Clerck) (Lepidoptera: Noctuidae) in the Pacific. Biological Control of Exotic Pests in the Pacific. In: Proceedings of a Plenary Session and Symposium, XIX International Congress of Entomology, Beijing, June 1992. Micronesia, 4 Supplement, 25-31.

Waterhouse DF, Norries KR. 1987. Othreis fullonia Clerk. In: Biological Control : Pacific Prospects, Inkata Press, Melbourne. pp 240-249. 